\title{
RT（ロボットテクノロジー）産業クラスター形成を目指す 大阪市
}

The Efforts by the Osaka City : for RT Robot-technology Industrial Cluster Formation

美濃地 研 一***大隡業創造館

Kenichi Minoji* *Business Innovation Center Osaka

\section{1. なぜ大阪でロボット産業を振興するのか}

大阪市では 2 年ほど前に, 市長自らが「大阪をロボット 産業で活性化したい!」と語ったことから，大阪市をあげ てロボットテクノロジーをビジネスに結び付けようとする 取り組みが始まった。

大阪は，かつて「東洋のマンチェスター」と呼ばれ，製 造業の拠点として名を馳せていたが, 近年は重厚長大型産 業の工場流出が相次ぐなど，かつてのような製造業の拠点 といったイメージはなくなった。ところが，人々の生活に かかわる次世代のロボット産業は，これから大きな成長が 期待される分野であり, また製造業の集積や大都市のサ一 ビス産業・生活者の存在が産業創出に大きく寄与するもの である、そこで, 大阪市では, ロボットテクノロジーを大 阪の産業再生や都市再生の起爆剤と位置づけ，大阪市をロ ボットビジネスの拠点とすべく，取り組みを始めている．大 阪産業創造館は, 大阪市経済局所管の外郭団体であり, 施 策の実施機関として, 現場での事業展開を担っている.

\section{2. 大阪市の RT 産業創出の取り組み}

このような背景から大阪市では「ものづくり再生プラン」, 「都市再生プログラム」にロボットテクノロジーにより生ま れる産業を大阪の未来を担うリーディング産業と位置づけ, 2003 年度から本格的に施策を展開している。

主な施策は以下の通り。

(1) 製造業実態調査（市内のロボット関連事業所のすべて に訪問面接調査を実施)

(2)「ロボット産業の振興」に関する市政モニター調査

(3)ロボット関連企業誘致活動

(4) ロボカップ世界大会 (2005 大阪大会) 招致活動およ びロボカップジャパンオープン 2004 大阪の開催準備 ここで示した(1)（3)の調査は，いずれも地方自治体の取り 組みとしては, 日本初のものである. (1)は事業所単位でロボ

原稿受付 2004 年 8 月 2 日

キーワード : Industrial Cluster, Robot Tehnology, Robot Laboratory, Dreamteam

* 个 541-0053 大阪市中央区本町 1-4-5

${ }^{*}$ Chuo-ku, Osaka-shi, Osaka
ット技術を把握した「日本初」のデータである. その結果につ いても公表に同意を得た企業 56 社のデータは, インターネッ 卜上で公開されている（大阪市ものづくり企業データベース, http://www.sansokan.jp/mono/search/search gyoshu1. php).

「(2)『ロボット産業の振興』に関する市政モニター調査」 は, 市民（600名）に, ロボットのイメージや生活をサポー トするロボットに対する意識などを質問している。実際に 寄せられた市民のニーズは，「生活をサポートするロボット に期待する」という回答が約 9 割に達し, 大きな期待が寄 せられていることが把握できた。「家の中で役に立つ場面」 としては,「ホームセキュリティー」「介護・看護」「掃除・ 洗濯などの家事」などの回答を得た。詳しくは, 以下のサ イトで記載されている。

http://www.city.osaka.jp/shimin/shingikai/03/ heisei15/tel01.html

「(3)ロボット関連企業誘致活動」については, 欧米・アジ アなどの海外のロボット関連企業や国内の関連企業へのア ンケート調査や, 海外企業の大阪への招聘およびマッチン グ機会の提供を行った。その結果，オーストラリアの企業 と市内企業のマッチングが成立するなど, 成果もあがりつ つある.そのほかにも，大阪市の海外事務所と連携して，パ リでロボットセミナーに参加し，フランス企業数十社にプ レゼンテーションするなど，国内外の企業に対して多面的 なアプローチを行っている.

「(4)ロボカップ世界大会（2005 大阪大会）招致活動およ びロボカップジャパンオープン 2004 大阪の開催準備」につ いては，2003年 7 月にイタリアのパドヴァ市で開催された ロボカップ世界大会期間中に，2005 年の世界大会を大阪市 で開催することが決定した。先に開催が決まっていた 2004 年のジャパンオープンとあわせて， 2 年続けてロボットに よるサッカー大会が大阪で開催されることとなった。ロボ カップに関しては, 全世界 35 ケ国, 約 4 千名のロボットや 人工知能の研究者が参画する世界的なネットワークができ あがっており，世界大会の開催でこれらの研究者が一堂に 会することは，世界的な RT 産業クラスター化を目指すう えで，大きな意義があると考えられる. 


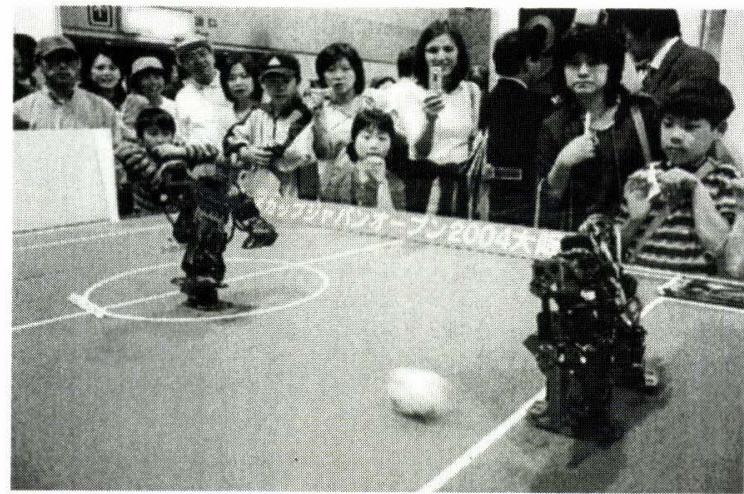

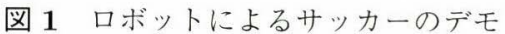

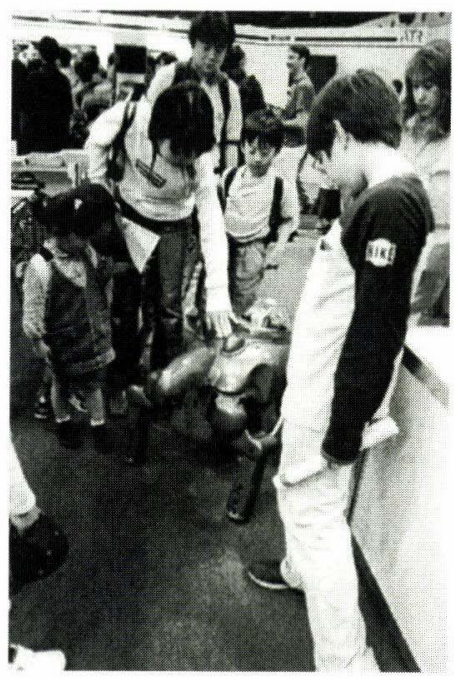

図 2 ロボットに触れ楽しさを実感

その世界大会の前哨戦と位置づけられる「ロボカップジャ パンオープン 2004」は，2004年 5 月に開催され，延ベ 13 万 人が来場するという大盛況のうちに終えることができた。ま た, 同じ会場で同時開催した展示会「ロボトレックス 2004」 も好評で，一般の方々にロボットを見て触れる貴重な機会 を提供できた（図 1，2）。

\section{3. 大阪産業創造館の RT 産業創出の取り組み}

大阪産業創造館に，2003 年度から新産業創造推進室が設 置され，大阪市が産業再生や都市再生の柱とする「ロボッ ト」や「ヘルスケア」産業の創出にも新たに取り組むこと になった。

これらの事業の中から主なものを紹介する。

(1) 次世代 RT 产業創出研究会の運営

(2) ロボカップジャパンオープン 2004 に参加するドリー ムチームの公募 · 運営

(3) ネットワークづくりと情報発信

(1) 次世代 RT 産業創出研究会

同研究会は, 座長に大阪大学浅田教授を迎之, 大阪を中
心に関西の産学官の主要なメンバーで構成されたもので, 大阪に RT を活用した産業クラスターを形成していくため には，どうすればよいかということを検討した。

最終的には，ロボットビジネスを支援する組織を NPO 化し，大阪市といった地域の朹組みにとらわれることなく， 全国そして世界からロボットビジネスにかかわる研究者や 企業人が集まるネットワークを整備しようということでま とめている.これを「RT協働プラットフォーム」と呼び, このようなソフトが整備され, ロボットビジネスが展開さ れるようになれば，ハード面での拠点も必要になってくる ため, その受け且として, 大阪駅北地区の再開発にあわせ て「RoboCity CoRE (ロボシティコア)」(CoRE: Center of Rt Experiments）を整備することを提言している。そ してその先に，大阪を中心とした世界的なロボット産業の クラスターをつくりあげるというシナリオを描いている。

しかし，こうした構想づくりだけでは実現性を伴わない ため, 2003 年秋からリーディングプロジェクトと称する実 証プロジェクトを研究会の参加メンバーが同時並行で立ち 上げた。その結果，クラスター形成のシナリオづくりの副 産物として，今後の動きが注目されるプロジェクトが生ま れるとともに，すでに大きな成果も生まれている，以下に， 簡単に内容を紹介する。

(1) 次世代ロボット開発ネットワーク構想

市内で部品加工業を経営している委員の一人から「ロボッ トの試作や見積もりを依頼される機会があったが, 中小企 業 1 社だけで対応することは難しく，ビジネスチャンスを 逃している。こうした依頼に対応できるネットワークをつ くれないか？」というエピソードの紹介があり，その委員 自らが，他の企業とも連携しながらネットワークづくりに 取り組んでいる。そして，現在，約 70 社のメンバーによる 組織化が実現し，ロボットイベントの受注，ロボット部品 加工・製作などの引合い，ロボット教材化の企画などの取 り組みが進展している。

(2) ソフトスキンセンサーコンソーシアム

公募の補助金獲得を目指して結成された産学のコンソー シアムの中から，世間の注目を集める成果が生まれている.

「国際ロボット展 2003」にコンソーシアムのメンバー企 業（(株）ココロ）が, 大阪大学石黒研究室との共同研究 の成果として展示したのが, 図 3 「アクトロイド」。これが きっかけとなり, 愛知万博への出展が決まるという成果が 得られている.

(3)リノベーションプロジェクト

富士通（株）の maron-1や（株）テムザックの番竜など， すでに市場に出ているロボットを対象に, その商品開発や 新しい使い方を探るプロジェクトである.

maron-1 は, 当館が集めた OL のモニター 100 人の前 でメーカー担当者と吉本興業所属のタレントの掛け合い 


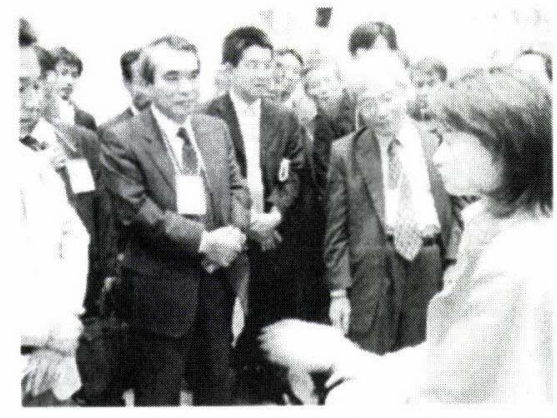

図 3 人工女優のまわりはいつも人だかり

によるプレゼン後，OLの視点で評価してもらい，OLの自 宅でモニタリングしてもらう企画が進んでいる.

番竜は「利用アイデア」を募集し，面白いアイデアを持っ ている方に実際に利用してもらい,これまでにないロボッ トの使い方を見出せればと期待している.

(4) 行政サービス関連プロジェクト

未だ市場として確立されていないロボットビジネスは, 官 公需によって，市場を作り，産業化の道筋をつけるべきだ と考えられている。市の関連施設である海遊館（年間 300 万人近くを集める西日本随一の水族館）での利用を考えて みようということになった。試作機を持ち込むなどの機会 を提供することで, 導入可能性を探っている.

(5) 教育プロジェクト

ロボットビジネスのなかで，比較的事業としての成立時 期が早いと考えられているのが，ロボットを使った教育関 連ビジネスである。ロボットを使った教育に携わっている 大学教官やロボットキット製作メーカー, 市内の試作・カ メラメーカーなどによるコンソーシアムを形成し, ジュニ ア向けのレスキューロボットの試作品製作を行った。実際 に，大会や見本市で実証テストを行っており，商品化に向 けての検討を進めている.

（2）ドリームチームの公募・運営

ロボカップジャパンオープン 2004 大阪のヒューマノイ ドリーグで優勝できる強いチームを地元から出場させたい ということで, ドリームチームという名称での産学共同の チームを募集した，出場するチームには，1,500 万円の補 助金が大阪市より助成された。

2004 年 5 月のロボカップジャパンオープンでは, ドリー ムチーム「TeamOSAKA」の「VisiON」(図4)が見事に 総合優勝を遂げた. 加えて, 7 月のポルトガルのリスボン で開催された世界大会でも優勝し, その完成度の高さを世 界にアピールすることができた。

加えて, VisiONのプロトタイプとなった 2 足歩行型の試 作機は, 2003 年秋には「Robovie-M (ロボビーM)」(図 5）として，市内のベンチャ一企業（ヴイストン（株））か ら市販されるに至り, VisiON 自体も受注生産の形で市販

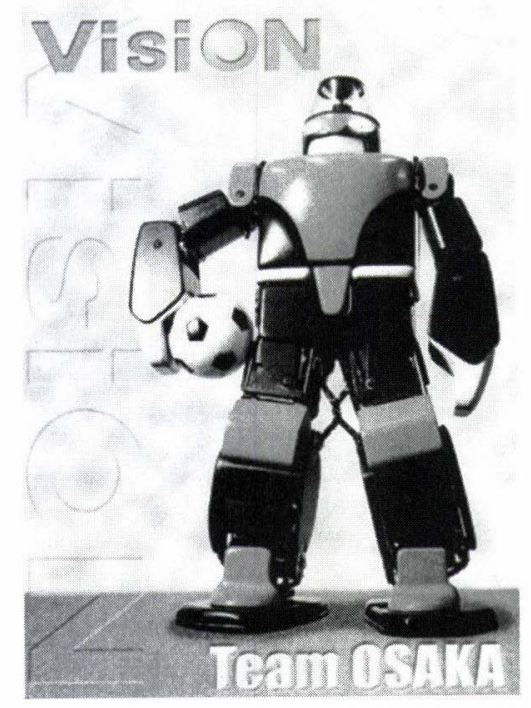

図 4 自律型 2 足歩行ロボット「VisiON」

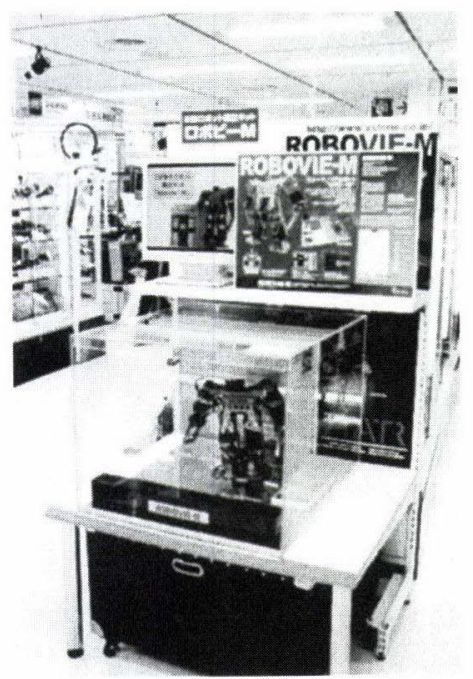

図 5 店頭販売中の「Robovie-M」

が決定し，ロボットビジネスを具体的に生み出すという一 つの目標を達成することができた.

さらに，もっとも大きな成果としては，このドリームチー ムの活動を紹介する $\mathrm{CM}$ が放映されることである. 公共広 告機構の提供により, TVにこのチームが登場する。広告 宣伝効果を広告費換算すれば, 補助金をはるかに上回る成 果を得ることができた。

(3) 関西地域や全国でのネットワークづくり

大阪圏のロボット産業振興の取り組みは，2004 年 4 月に 政府の都市再生プロジェクトの決定を得ているが, 関西地 域全体で産学官が連携して取り組んでいることが評価され ている.

当館も「関西次世代ロボット推進会議（事務局：関西経 済連合会)」,「ものづくりクラスター推進協議会（近畿経 




図 6 b-platzpress 保存版「ロボット特集号」

済産業局が推進するプロジェクト)」,「ロボット課題解決研 究会 (主催：大阪商工会議所)」の主要なメンバーとして活 動している，大阪市域にとどまらず，関西全体のロボット ビジネスを支援する取り組みのワンストップサービス機能 を担っている。

さらに，関西地域にとどまらず，全国的な組織である「ネッ トワークロボットフォーラム」,「ロボットサービスイニシア チブ」などにもメンバーとして参画し，また，NEDO 技術 開発機構の公募調査案件「新たな二ーズに即応したロボッ トの普及支援に関する調査」を受託し，全国的な視点での 調査も行った。こうした活動によって，日本ロボット工業 会や関係省庁とのつながりも徐々にできてきた。

（4）大阪オリジナルの情報発信を重視

当館では，ロボットのみならず，各種事業においても，広 報や PR を重視して扔り，抄客様のところへ情報を届ける ことができなければ，いくら良い取り組みをしていても，意 味がないと自戒しながら事業に取り組んでいる。

大阪市および大阪産業創造館のロボット産業振興に向け た取り組みを紹介した広報誌は増刷を重水，6万数千部を 配布し終えた（図 6).Web サイトもゼロから立ち上げ，現 在はリニューアルを終え, 2 代目となっている。 また, メ一 ルマガジンも約 1 年前から発行し始め, 今では 2,500 名も の方々に購読していただくまでになっている.

\section{4. 大阪市および大阪産業創造館の今後の取り組み}

大阪市では, 2004 年度は「ロボカップ世界大会」の準備 に力を入れている，それと同時に，大阪産業創造館に事業を 委託する形で，2005 年の世界大会に出場するドリームチー ムの募集・運営, ロボットラボラトリー(フューチャーラ イフデザインラボラトリー・ロボットフォーラム) (仮称) の整備・運営, 実用化を目指寸産学コンソーシアムの研究

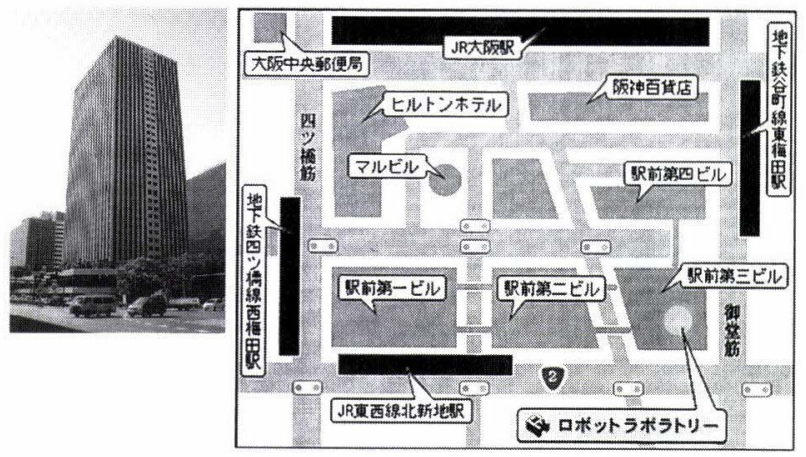

図 72004 年秋オープン予定のロボットラボ入居ビル案内図

開発助成に対する予算を組んでいる。

また，当館独自のプログラムも数多く用意されている.日 本初のロボットをテーマとした MOT 講座などもその一つ である。

（1）ロボットラボラトリーの整備

なかでも, 重要なのがロボットラボラトリーの整備であ る. 大阪駅前の都心の再開発ビル内の $300\left[\mathrm{~m}^{2}\right]$ 弱のスペー 久を改装し, ロボットテクノロジーに関わる研究者, 企業 が集い, 交流する拠点を整備する。ここは, ロボットテク， ロジーを活用した「便利で豊かな未来の生活を提案し, 生 み出す場」としていく(図 7).

【ロボットラボラトリーの主な活動と機能】

・未来の生活に役立つテクノロジーに関わる研究者・技 術者の交流

・ロボットテクノロジーが生み出す未来の生活の提案

・市場での実証実験プロジェクト運棠

・ロボットテクノロジー産業のシーズ探索

ロボットテクノロジーを核としたこのような機能を有す る拠点は, 地方自治体としては日本初である。この拠点が 多くの成果を生み出すことになれば，「ロボシティコア」や 「産業クラスター形成」にも弾みがつくはずである。

(2) 各種公募事業の実施

ロボットラボラトリーというハードの整備とともに, ソ フト面の強化にもさらに力を入れている。「ドリームチー ム, 教育教材開発, 産学コンソーシアムの研究開発助成」 など, 大阪市の単独事業での公募事業を展開している。こ れらの公募については, その開発プロセスを公開し, 研究 開発へその結果をフィードバックする仕組みを用意し，ラ ボのハードと公募のソフトを両輪として運営していくこと を想定している，ぜひとも全国の企業や大学の関係者に関 与していただきたいと考えている。

(3) 大阪产業創造館独自の事業展開

こうした大阪市からの委託事業に加えて, 当館では, 口 ボット実証実験の環境整備を進めるために構造改革特区の 提案を検討したり，実証実験の場として活用してもよいと 
いう施設を開拓するといったことも手がけている。

実際には，この誌面には書ききれない事業もたくさんあ る。ご興味をお持ちいただければ，まずはご連絡いただき たい．民間出身スタッフがみなさんから寄せられるご意見・ ご要望をもとに，機動的に事業を運営しており，他の行政 の外郭団体とは，一味違うサービスを提供できるはずと自 負している.

\section{5. 最後に〜地域産業クラスターとともに，ロボット 産業都市連合の形成も重要}

ロボット産業は，国際的に見ても日本に残された数少な い産業フロンティアである。しかし，実証実験の実施一つ をとっても，様々な困難がある。また，大阪市だけではな く，他の地域でも産業クラスターづくりを進めているが，そ のような前例もなく，試行錯䛊を繰り返している。そこで， 悩みやその解決策をともに共有し，お互いに学んだり, 気 ゔくことのできるような「ロボット産業都市連合」の形成
を提案したい。地域の現場のニーズを国に対して連帯して 提言する機能も持たせることができる。各地域の方にぜひ とも検討をお願いしたい.

\section{参 考 文 献}

[1] 大阪市：次世代 RT 産業創出研究会報告書, 2004 年 3 月.

[2]井上博允：“人間型ロボットが拓く未来社会と新産業の創成”, 日本口 ボット学会誌, vol.22, no.1, pp.2-5, 2004.

[ 3 ] 美濃地研一：“大阪市における RT 産業クラスター形成に向けた取り 組み”、ロボット, no.158, pp.20-26, 2004.

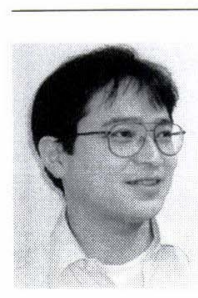

\section{美濃地研一（Kenichi Minoji）}

1967 年 8 月生. 1990 年神戸大学法学部法律 学科卒業. 1990 年 (株) 三和総合研究所入 社. 2002 年 (株) UFJ 総合研究所主任研究 員. 2003 年大阪産業創造館へ出向. 現在, 同 館シニアプランナー。 2004 年香川大学大学院 地域マネジメント研究科非常勤講師. 次世代 ロボット産業振興, 地域マネジメントの実務と研究に従事. 